\title{
Serum S100A12 (EN-RAGE) Levels in Patients with Decreased Renal Function and Subclinical Chronic Inflammatory Disease
}

\author{
Oskar Zakiyanov ${ }^{a, b}$ Marta Kalousováb Vítězslav Kř́ha ${ }^{c}$ Tomáš Zima $^{b}$ \\ Vladimír Tesařa \\ a Department of Nephrology and ${ }^{\mathrm{b}}$ Institute of Clinical Biochemistry and Laboratory Diagnostics, First Faculty of \\ Medicine, Charles University in Prague and General University Hospital in Prague, and 'Department of Physics, \\ Faculty of Electrical Engineering, Czech Technical University in Prague, Prague, Czech Republic
}

\section{Key Words}

Calcium-binding protein · Chronic kidney disease •

EN-RAGE · Hemodialysis • Inflammation • Protein •

$\mathrm{S} 100 \mathrm{~A} 12 \cdot \mathrm{sRAGE}$

\begin{abstract}
Background: The calcium-binding protein S100A12 (ENRAGE) causes inflammation through interaction with the multiligand receptor for advanced glycation end products (RAGE). The aim of the study was to determine S100A12 levels and describe their relationship to inflammatory markers in patients with decreased renal function. Methods: The studied group consisted of 46 patients with various degrees of chronic renal insufficiency (CHRI), 31 long-term hemodialysis (HD) patients and 24 healthy controls. S100A12 and soluble RAGE were assessed immunochemically (ELISA), and routine biochemical parameters were measured. Results: S100A12 levels were not different in CHRI (166 $\pm 140 \mathrm{ng} / \mathrm{ml})$ and HD patients (127 $\pm 101 \mathrm{ng} / \mathrm{ml})$ compared to controls (126 \pm 106 $\mathrm{ng} / \mathrm{ml} ; \mathrm{p}=0.20$, n.s.). In CHRI patients, S100A12 correlated with C-reactive protein (CRP) levels, orosomucoid, and inversely with $\alpha_{2}$-macroglobulin. In HD patients, S100A12 cor-
\end{abstract}

related with age, CRP, orosomucoid, fibrinogen and leukocyte levels. In multivariate regression analysis after adjustment for age, S100A12 levels remained correlated with: orosomucoid in CHRI patients; CRP, leukocytes, fibrinogen and negatively with sRAGE in HD patients; and leukocytes in controls. Conclusions: Although S100A12 levels were not elevated in patients with decreased kidney function, a relation to markers of inflammation was found. Further studies are required to demonstrate the significance of S100A12 in patients with decreased renal function.

Copyright $\odot 2011$ S. Karger AG, Basel

\section{Introduction}

Patients with chronic kidney disease (CKD) are characterized by an increased risk of cardiovascular complications [1-3]. There is unequivocal evidence linking this risk and endothelial dysfunction in CKD and hemodialysis (HD) patients $[4,5]$. Several examples of testing potential markers of inflammation, oxidative stress and endothelial function have been presented [6-8]. Measuring such biomarkers of inflammation and oxidative stress

\section{KARGER}

Fax +41613061234 E-Mail karger@karger.ch www.karger.com
(C) 2011 S. Karger AG, Basel

$1420-4096 / 11 / 0346-0457 \$ 38.00 / 0$

Accessible online at:

www.karger.com/kbr
Prof. Marta Kalousová, MD, PhD

Institute of Clinical Chemistry and Laboratory Diagnostics, First Faculty of Medicine Charles University in Prague and General University Hospital in Prague

$\mathrm{Na}$ Bojišti 3, CZ-128 00 Prague 2 (Czech Republic)

Tel. +420 224964 212, E-Mail marta.kalousova@ seznam.cz 
may better define the risk profile of cardiovascular complications in CKD patients. Since the interaction of S100A12 with multiligand receptors plays a key role in inflammatory responses, this protein could serve as a novel marker of vascular inflammation, possibly related to patient outcome.

The receptor for advanced glycation end products (RAGE) is a member of the immunoglobulin superfamily of cell surface proteins that interacts with a wide range of ligands, including advanced glycation end products, modified low-density lipoproteins, amyloid fibrils, amphoterin (HMGB1) and various S100 proteins [9]. Ctruncated RAGE (endogenous secretory RAGE; esRAGE) isoforms lacking the transmembrane domain and other RAGE isoforms, cleaved proteolytically from membrane receptor via metalloproteinases, circulate in the plasma, where they can act as a decoy for RAGE ligands. These secreted variants together represent the total amount of soluble RAGE (sRAGE) that can be detected in the bloodstream $[10,11]$. It has been suggested that sRAGE exerts a protective role against development of atherosclerotic cardiovascular disease $[12,13]$.

The calcium-binding protein S100A12, also known as EN-RAGE (extracellular newly identified RAGE-binding protein), is a ligand for RAGE that is expressed on macrophages, lymphocytes and the endothelium. Binding of S100A12 to RAGE activates the intracellular signaling cascades leading to proinflammatory responses in target cells including upregulation of adhesion molecules on the endothelium [14]. S100A12 has potent chemotactic activity which is comparable with that of other strongly chemotactic agents such as C5a or fMLP [15-17]. S100A12 is overexpressed at sites of local inflammation, and serum concentrations of S100A12 correlate with an individual's disease activity [18-20].

Atherosclerosis is now assumed to be a subclinical chronic inflammatory disease [21]. Subclinical chronic systemic inflammatory processes are characterized by increased circulating levels of proinflammatory cytokines and cytokine-responsive acute-phase proteins. Accelerated atherosclerosis is one of the consequential complications of CKD and HD [22], and S100A12 might be an early marker of this process.

The aim of the study was to determine S100A12 levels and describe their relationship to inflammatory markers in patients with decreased renal function including HD patients.

\section{Methods}

Patients and Controls

S100A12 was studied in patients with CKD and various degrees of chronic renal insufficiency (CHRI), HD patients and healthy controls. Detailed characteristics of patients and controls are listed in table 1 . All patients had a stable clinical status at the time of the study, without signs of acute infection or acute cardiac problems. A sub-analysis was performed comparing S100A12 values in patients with CRP levels $<6.5$ and $>6.5 \mathrm{mg} / \mathrm{l}$ in both study groups.

Patients with CKD. The group of CKD patients not yet dialyzed (CHRI group) consisted of 46 patients. Their glomerular filtration rate ranged from 0.10 to $2.137 \mathrm{ml} / \mathrm{s} / 1.73 \mathrm{~m}^{2}$ (median $0.39 \mathrm{ml} / \mathrm{s} / 1.73 \mathrm{~m}^{2}$ ), and proteinuria ranged from 0.04 to 11.6 $\mathrm{g} / 24 \mathrm{~h}$. The duration of their renal diseases was from a minimum of 5 months to a maximum of 31 years. Causes of nephropathy were immunoglobulin A nephritis in 11 patients, membranous nephropathy in 2 patients, hypertensive nephropathy in 13 patients, diabetic nephropathy in 3 patients, interstitial nephritis in 7 patients, cystic kidney disease in 6 patients, and multifactoral in 4 patients. The majority of the patients had hypertension, and were treated with moderate doses of antihypertensive drugs. Twenty-six patients had dyslipidemia and were treated with statins.

Patients with End-Stage Renal Disease Treated with HD. This group (HD group) consisted of 31 long-term HD patients. Causes of renal failure were as follows: glomerulonephritis in 4 patients, hypertensive nephropathy in 4 patients, cystic kidney disease in 7 patients, interstitial nephritis in 5 patients, diabetic nephropathy in 4 patients, and multifactoral in 7 patients. Their mean residual diuresis was $660 \pm 694 \mathrm{ml} / 24 \mathrm{~h}$. The majority of patients were dialyzed 3 times/week for $4 \mathrm{~h}$, and their dialysis treatments had lasted from 3 months to 17 years. They received 1,500 $\pm 658 \mathrm{IU}$ heparin per session; their mean ultrafiltration rate was $598 \mathrm{ml} / \mathrm{h}$, and $\mathrm{Kt} / \mathrm{V} 1.46 \pm 0.2$. HD treatment was performed using conventional bicarbonate-buffered dialysate in all patients. Of all patients, $91 \%$ used native arteriovenous fistulae for dialysis; in other cases arteriovenous fistulae with artificial graft were used. Ten patients were dialyzed with high-flux dialyzers, and in the rest of the group low-flux dialyzers were used. Dialyzers were made of polysulfone (35.5\%), diacetate cellulose (48.3\%) and triacetate cellulose (16.2\%). The majority of the patients had hypertension and were treated with moderate doses of antihypertensive drugs. Eight patients had type 2 diabetes (DM) treated with insulin or peroral antidiabetics. Fourteen patients had dyslipidemia treated by statins. They were administered an average weekly erythropoietin of 109 IU/kg body weight.

Control Group. The control group consisted of 24 healthy subjects. They were not administered any special alimentary supplements at the time of the study.

The study was performed in adherence with the principles of the Declaration of Helsinki and approved by the Institutional Ethical Committee. All participants gave their informed consent prior to entering the study.

Samples

In HD patients, blood was collected via puncture of the arteriovenous fistula before starting the dialysis session and prior to 
Table 1. Clinical and laboratory data of control subjects and patients with decreased renal function

\begin{tabular}{|c|c|c|c|c|}
\hline & HD patients & CHRI patients & Control subjects & $\begin{array}{l}\mathrm{p} \\
(\mathrm{ANOVA})^{1}\end{array}$ \\
\hline n (men/women) & $31(15 / 16)$ & $46(29 / 17)$ & $24(19 / 5)$ & \\
\hline Age, years & $59 \pm 16$ & $60 \pm 16$ & $43 \pm 9$ & $<0.0001$ \\
\hline Hypertension, $\mathrm{n}$ & 29 & 43 & 0 & \\
\hline History of cardiovascular disease, $\mathrm{n}$ & 13 & 12 & 0 & \\
\hline Diabetes mellitus, $\mathrm{n}$ & 8 & 14 & 0 & \\
\hline Dyslipidemia, $\mathrm{n}$ & 16 & 29 & 0 & \\
\hline BMI & $24.4 \pm 4.1$ & $26.9 \pm 5.0$ & $25.6 \pm 3.4$ & 0.03 \\
\hline Cholesterol, mmol/1 & $4.2 \pm 1.01$ & $4.6 \pm 1.0$ & $5.3 \pm 1.1$ & $<0.0001$ \\
\hline HDL cholesterol, $\mathrm{mmol} / \mathrm{l}$ & $1.1 \pm 0.4$ & $1.2 \pm 0.3$ & $1.4 \pm 0.3$ & $<0.0001$ \\
\hline LDL cholesterol, mmol/l & $2.4 \pm 1.0$ & $2.6 \pm 0.9$ & $3.2 \pm 0.9$ & 0.008 \\
\hline Triglycerides, $\mathrm{mmol} / \mathrm{l}$ & $2.0 \pm 1.1$ & $2.4 \pm 0.4$ & $1.5 \pm 0.8$ & 0.06 \\
\hline Albumin, $g / 1$ & $40.7 \pm 3.3$ & $41.4 \pm 4.9$ & $48.5 \pm 2.7$ & $<0.0001$ \\
\hline $\mathrm{CRP}, \mathrm{mg} / \mathrm{l}$ & $10.9 \pm 11.2$ & $7.3 \pm 8.2$ & $6.1 \pm 2.4$ & 0.03 \\
\hline Orosomucoid, g/l & $1.0 \pm 0.4$ & $1.2 \pm 0.5$ & n.a. (reference range: $0.50-1.20$ ) & $0.21^{2}$ \\
\hline$\alpha_{2}$-Macroglobulin, g/l & $2.0 \pm 0.8$ & $2.1 \pm 0.7$ & n.a. (reference range: $1.3-3.0$ ) & $0.54^{2}$ \\
\hline Fibrinogen, $g / 1$ & $4.8 \pm 1.5$ & $4.7 \pm 1.4$ & n.a. (reference range: $2-4$ ) & $0.60^{2}$ \\
\hline Hemoglobin, g/l & $108 \pm 10$ & $119 \pm 14$ & $144 \pm 8$ & $<0.0001$ \\
\hline Leukocytes, $\times 10^{9} / 1$ & $7.5 \pm 2.5$ & $7.9 \pm 2.3$ & $5.9 \pm 1.3$ & $<0.0001$ \\
\hline S100A12 (EN-RAGE), ng/ml & $127 \pm 101$ & $166 \pm 140$ & $126 \pm 106$ & 0.20 \\
\hline $\mathrm{sRAGE}, \mathrm{pg} / \mathrm{ml}$ & $2,747 \pm 1,239$ & $2,271 \pm 1,104$ & $850 \pm 275$ & $<0.0001$ \\
\hline S100A12/sRAGE ratio & $0.06 \pm 0.06$ & $0.09 \pm 0.09$ & $0.21 \pm 0.25$ & 0.008 \\
\hline
\end{tabular}

Data expressed as means $\pm \mathrm{SD}$, unless otherwise indicated. n.a. $=$ Not assessed.

${ }^{1}$ Adjusted for age. ${ }^{2}$ Assessed using t test.

heparin administration. In other subjects, blood was collected after overnight fasting via puncture of the cubital vein, simultaneously with blood collection for routine control examinations. Blood was centrifuged for $10 \mathrm{~min}$ at $1,450 \mathrm{~g}$, and serum was frozen at $-80^{\circ} \mathrm{C}$. Additionally, in a randomly selected sample consisting of about half of the patients with renal insufficiency and not yet dialyzed, a 24-hour urine sample was collected, frozen and also used for analysis. Analysis of all samples was performed within 6 months after collection.

\section{Laboratory Parameters}

S100A12 Assay. S100A12 was measured by means of a sandwich enzyme-linked immunosorbent assay using standard kits (Abnova, Taipei, Taiwan, www.abnova.com) according to the manufacturer's protocol. Results are given in nanograms per milliliter ( $\mathrm{ng} / \mathrm{ml})$.

sRAGE Assay. sRAGE was measured using a commercially available sandwich ELISA kit according to the instructions of the manufacturer (Quantikine; R\&D Systems, Inc., Minneapolis, Minn., USA, www.rndsystems.com). Results are given in picograms per milliliter $(\mathrm{pg} / \mathrm{ml})$.

Other Parameters. C-reactive protein (CRP) was determined turbidimetrically, orosomucoid (acidic $\alpha_{1}$-glycoprotein) was assessed nephelometrically and fibrinogen was measured by the thrombin method (Clauss). Glomerular filtration rate was calculated by 24-hour urine collection.

S100A12 in Decreased Renal Function and Subclinical Inflammation
Routine biochemical parameters were determined by standard clinical chemistry methods using automated analyzers.

\section{Statistical Analysis}

Results are expressed as means \pm SD. ANOVA, Mann-Whitney test and $t$ test adjusted for age using general linear model were used for evaluation of differences among groups. Associations between parameters were determined by using Spearman correlation coefficients. Stepwise multivariate regression analysis adjusted for age was used to assess independent predictors of S100A12. All results are considered statistically significant at $\mathrm{p}<0.05$. All tests were performed using InStat software (GraphPad Software, Inc., La Jolla, Calif., USA, www.graphpad.com).

\section{Results}

S100A12 levels were not different in CHRI and HD patients compared to controls adjusted for age (166 \pm 140 $\mathrm{ng} / \mathrm{ml}$ in CHRI patients and $127 \pm 101 \mathrm{ng} / \mathrm{ml} \mathrm{HD} \mathrm{pa-}$ tients vs. $126 \pm 106 \mathrm{ng} / \mathrm{ml}$ in controls, $\mathrm{p}=0.27$, n.s.). Comparing patients with higher and lower CRP levels, higher levels of S100A12 were found in patients with higher CRP values in both studied groups: HD patients 
Table 2. Factors associated with S100A12 (EN-RAGE) in all studied groups

\begin{tabular}{|c|c|c|c|c|c|c|}
\hline $\begin{array}{l}\text { Studied group with } \\
\text { independent variables }\end{array}$ & B-coefficient & SE & $\mathrm{t}$ & $\mathrm{p}$ & Intercept & $\mathrm{R}^{2}$ \\
\hline Controls: leukocytes & 36.78 & 15.37 & 2.39 & 0.025 & -90.30 & 0.20 \\
\hline CHRI: orosomucoid & 108.927 & 41.18 & 2.64 & 0.0112 & 35.30 & 0.1372 \\
\hline HD: leukocytes & 12.64 & 4.81 & 2.62 & 0.014 & -11.89 & 0.756 \\
\hline fibrinogen & 18.29 & 7.69 & 2.37 & 0.025 & & \\
\hline $\mathrm{CRP}$ & 3.75 & 0.66 & 5.66 & $<0.0001$ & & \\
\hline sRAGE & -0.0033 & 0.0088 & -3.84 & $<0.001$ & & \\
\hline
\end{tabular}

Multivariate stepwise regression analysis using serum S100A12 as the dependent variable (adjusted for age).

$(174 \pm 125 \mathrm{ng} / \mathrm{ml}, \mathrm{n}=15$ vs. $84 \pm 43 \mathrm{ng} / \mathrm{ml}, \mathrm{n}=16, \mathrm{p}=$ $0.03)$ and CHRI patients $(237 \pm 178 \mathrm{ng} / \mathrm{ml}, \mathrm{n}=17$, vs. 124 $\pm 94 \mathrm{ng} / \mathrm{ml}, \mathrm{n}=29, \mathrm{p}=0.02)$.

Hence, no relationship between S100A12 and serum creatinine concentrations was found in CKD patients. In 17 of 19 patients with nephropathy, S100A12 was detectable in urine samples (mean $453.1 \pm 445.6 \mathrm{ng} / \mathrm{ml}$ ) and correlated with serum creatinine levels $(\mathrm{r}=0.53, \mathrm{p}=0.03)$. S100A12 levels in urine of measured CHRI patients were significantly higher in comparison with serum S100A12 levels $(p=0.02)$. No correlation with proteinuria was observed.

No difference in serum S100A12 levels was observed between patients with DM and those without DM in CHRI patients $(157.13 \pm 123.85 \mathrm{ng} / \mathrm{ml}$ vs. $169.87 \pm$ $149.28 \mathrm{ng} / \mathrm{ml}, \mathrm{p}=0.78$, n.s.). In HD patients, there was a trend towards higher S100A12 levels in patients with DM than those without DM $(182.86 \pm 136.68 \mathrm{ng} / \mathrm{ml}$ and $108.15 \pm 81.80 \mathrm{ng} / \mathrm{ml}, \mathrm{p}=0.07$ was of borderline significance).

In CHRI patients, S100A12 correlated with CRP levels $(\mathrm{r}=0.46, \mathrm{p}=0.001)$, orosomucoid $(\mathrm{r}=0.35, \mathrm{p}=0.02)$, and inversely with $\alpha_{2}$-macroglobulin $(r=-0.3, p=0.04)$. Correlations with leukocyte count were of borderline significance $(\mathrm{r}=0.26, \mathrm{p}=0.07)$. In HD patients, S100A12 correlated with age $(\mathrm{r}=0.42, \mathrm{p}=0.02)$, CRP $(\mathrm{r}=0.56, \mathrm{p}=$ $0.001)$, orosomucoid $(\mathrm{r}=0.4, \mathrm{p}=0.04)$, fibrinogen $(\mathrm{r}=$ $0.54, \mathrm{p}=0.002)$, and leukocy te count $(\mathrm{r}=0.60, \mathrm{p}=0.0004)$. S100A12 was not correlated with CRP $(r=0.03, p=0.9)$ and leukocyte count $(\mathrm{r}=0.24, \mathrm{p}=0.25)$ in control subjects.

We found that S100A12 was not correlated with triglyceride, cholesterol or lipoprotein concentrations in either the CHRI or HD groups. In addition, serum levels of S100A12 were not significantly different among patients with dyslipidemia treated with statins and those without this treatment in both CHRI $(170 \pm 122$ vs. $152 \pm 164$ $\mathrm{ng} / \mathrm{ml}, \mathrm{p}=0.4)$ and HD (137 \pm 123 vs. $113 \pm 70 \mathrm{ng} / \mathrm{ml}$, $\mathrm{p}=0.9)$ groups.

In addition, serum levels of S100A12 were not significantly different among patients treated with angiotensin converting enzyme inhibitors or sartans (ACEI/ABR) and those without this treatment in both CHRI (168 \pm $154 \mathrm{ng} / \mathrm{ml}, \mathrm{n}=34$, vs. $159 \pm 98 \mathrm{ng} / \mathrm{ml}, \mathrm{n}=12, \mathrm{p}=0.6$ ) and $\mathrm{HD}(148 \pm 121 \mathrm{ng} / \mathrm{ml}, \mathrm{n}=16$, vs. $105 \pm 73 \mathrm{ng} / \mathrm{ml}$, $\mathrm{n}=15, \mathrm{p}=0.3)$ groups.

We performed a stepwise multivariate regression analysis of contributing factors to explain S100A12 levels in all studied groups. Table 2 shows the results of stepwise multivariate analysis after adjustment for age of factors predicting S100A12 levels: orosomucoid in CHRI patients; CRP, leukocyte count, fibrinogen and negatively sRAGE in HD patients; and leukocyte count in healthy controls.

In summary, S100A12 levels were not elevated in CKD and HD patients compared to controls. Nevertheless, in a subgroup of patients with higher CRP levels in contrast to the whole population, S100A12 values were increased in both CHRI and HD patients. In CKD patients not yet dialyzed, S100A12 levels were related to orosomucoid as an inflammatory marker. In HD patients S100A12 levels also correlated to markers of inflammation such as CRP, leukocyte count, fibrinogen, and negatively to sRAGE. In healthy controls, S100A12 levels were related to leukocyte count.

These results suggest that serum S100A12 levels are regulated by factors related to subclinical inflammation in patients with CKD. S100A12 is also present in the urine, and urine concentrations are higher compared to serum levels and correlate with serum creatinine. 


\section{Discussion}

This study shows that levels of S100A12 were not different in not-yet-dialyzed CKD patients with different degrees of renal insufficiency and HD patients compared to healthy controls. The patients were all in stable clinical status at the time of the study without signs of acute infection or acute cardiac problems. However, in a subgroup of patients with higher CRP levels (in contrast to the whole studied population), the S100A12 values were increased. Thus, we suggest that although serum S100A12 levels are not increased during basal conditions, the presence of subclinical inflammation is likely to result in the higher levels of S100A12 in CKD and HD patients. In addition, we detected significantly higher S100A12 levels in the urine of CKD patients than those found in the serum. Urine concentrations of S100A12 correlated with serum creatinine, but not with serum S100A12 levels.

These results are in contrast with the finding of Mori et al. [23], where levels of S100A12 were significantly higher in HD patients with atherosclerosis. The same authors also reported a significant increase in S100A12 concentrations in patients on continuous ambulatory peritoneal dialysis [24]. This discrepancy could be due to the relatively small sample size in this study and also to the heterogeneity of the study population [23]. Further studies are necessary to clarify this issue.

In line with previous reports $[25,26]$, our study confirms that serum sRAGE levels are elevated in patients with decreased renal function in both patients with CKD and HD patients as compared with those in healthy controls. Also the S100A12/sRAGE ratio appears to be more favorable in CKD and HD patients than in the controls. sRAGE concentrations increase with declining renal function and significantly decrease after renal transplantation $[27,28]$. The precise mechanism of sRAGE increase in patients with declining renal function is still unknown, suggesting either a decreased clearance of sRAGE accompanying the decline in renal function, or its upregulation as a protective factor against toxic effects of advanced glycation end products (AGEs) in patients with progressing loss of renal function [25, 29]. In HD patients, levels of sRAGE are elevated in comparison with healthy subjects, and might modulate vascular and inflammatory reaction during dialysis. Other causes such as stimulation of neutrophils on the dialysis membrane, puncture of arteriovenous fistula, and heparin administration might participate in increased serum S100A12 levels in HD patients [26].

S100A12 in Decreased Renal Function and Subclinical Inflammation
In stepwise multivariate regression analysis after adjustment for age, S100A12 levels remained correlated with inflammatory markers in all studied groups: orosomucoid in CHRI patients; CRP, leukocyte count, fibrinogen and inversely sRAGE in HD patients; and leukocyte count in healthy controls. It is conceivable that S100A12 might contribute to some of the risk for inflammation associated with renal impairment.

Considering the proinflammatory functions of S100A12, it is possible that neutrophil-derived S100A12 might be involved in an inflammatory process in CKD and HD patients. Correlations of serum S100A12 levels with inflammatory parameters (CRP, orosomucoid, negatively with $\alpha_{2}$-macroglobulin) in CKD patients and (CRP, orosomucoid, fibrinogen, in addition to leukocyte count) in HD patients in this study support this possibility. Indeed, S100A12 is secreted from activated neutrophils and exerts its proinflammatory effects on the endothelium and leukocytes via binding to RAGE expressed on these cells $[17,19]$. Interaction of EN-RAGE (S100A12) with cellular RAGE on the endothelium, mononuclear phagocytes and lymphocytes triggers cellular activation with generation of key proinflammatory mediators [14]. Low sRAGE and high S100A12, but not CML [ $\mathrm{N} \varepsilon$-(carboxymethyl)-lysine-protein adducts], were strongly associated with an increased risk for cardiovascular disease (Framingham score) in diabetic and non-diabetic subjects. Thus, the inverse correlation between S100A12 and sRAGE suggests that chronic proinflammation, including atherosclerosis, may upregulate plasma S100A12 levels, which in turn decreases plasma sRAGE levels [30]. Recently, Nakashima et al. [29] showed that S100A12 and sRAGE are elevated and have opposite associations with inflammation in prevalent HD patients.

In addition, S100A12 was also isolated, via drug-affinity chromatography, as a protein binding to three different anti-allergic drugs: amlexanox, cromolyn and tranilast [31]. It is feasible that exaggerated release of this S100A12 protein at sites of inflammation induces a positive feedback loop in which primed phagocytes and S100A12-stimulated endothelium facilitate the further recruitment of even more leukocytes [19].

In accordance with the study by Basta et al. [32], we also found a close association in univariate analysis between hsCRP and serum S100A12 levels in CKD patients. Hasegawa et al. [33] demonstrated that levels of mRNA/protein of S100A12 were enhanced by another proinflammatory molecule, i.e. IL-6 in cultured THP-1 cells. S100A12 serum concentrations indicate neutrophil

Kidney Blood Press Res 2011;34:457-464 
activation in Crohn's disease [19], juvenile rheumatoid arthritis [20], rheumatoid and psoriatic arthritis [34], cystic fibrosis [35], Kawasaki disease [36], MPO-ANCA (myeloperoxidase anti-neutrophil cytoplasmic antibody)-associated glomerulonephritis [37] and type $2 \mathrm{DM}$ [38].

Atherosclerosis has an inflammatory etiology, and elevated CRP in patients with atherosclerosis not only serves as a biomarker for cardiovascular disease risk, but it also functions as an active mediator of atherosclerosis by its direct proatherogenic effects on vasculature [21, 39]. Moreover, CRP and orosomucoid were shown to be the inflammatory markers in different stages of CKD [40]. Mahajan et al. [41] suggested that CRP is able to augment mRNA expression of both RAGE and S100A12 genes. Augmented expression of S100A12 in the presence of CRP points to close correlation between S100A12 and activation of granulocytes and monocytes under inflammatory conditions. The parallel trend observed for the increased expression of RAGE and its ligand represents an attractive model to explain how RAGE and its proinflammatory ligand S100A12 contribute to the pathophysiology of various inflammatory diseases including atherosclerosis [42]. Orosomucoid displays also several activities on one cell type: on neutrophils it influences chemotaxis, superoxide generation and aggregation [43]. Orosomucoid, being an acute-phase reactant, contributes to the general function of the acute-phase response as a coordinated system that modulates host immune response during periods of intense inflammation and tissue destruction.

Although there were no differences in S100A12 levels in CHRI and HD patients with and without statin therapy in this study, probably due to the small sample size, the beneficial effect of lipid-lowering therapy on S100A12 levels cannot be excluded in CKD patients. Recently, it was shown that atorvastatin treatment significantly attenuated CRP-induced RAGE and S100A12 expression in THP-1 cells [41], indicating the importance of anti-inflammatory properties of atorvastatin which may be mediated by non-steroidal products of the mevalonate pathway.

Angiotensin-converting enzyme 1 inhibitors are also another factor that may potentially modulate the AGERAGE pathway [44]. We did not observe a significant difference in S100A12 levels in relation to treatment with ACEI/ABR in our patients with decreased renal function. However, a larger cohort of patients should be tested to confirm or exclude the effect of the above-mentioned drugs on S100A12 levels in this population.
This study has some limitations. First, our study was limited by its observational nature, which allowed us to establish associations, but not causality. Second, the studied groups were older than the controls. We performed the general linear regression and multivariate analysis with appropriate adjustment to age. Third, because the S100A12 protein has been measured in a small sample of subjects, our data need to be confirmed in a larger cohort of patients.

In conclusion, S100A12 (EN-RAGE), a sensitive and specific marker of localized inflammatory process, is not elevated in patients with decreased renal function at stable clinical status without signs of overt inflammation. Even in these basal conditions, it is significantly related to inflammatory markers. In addition, this study also shows that S100A12 is present in the urine, and urine levels are higher in comparison with those in serum, and correlate with renal function. This finding warrants further investigation to understand the importance of S100A12 in the inflammatory process, and to determine its utility as an inflammatory biomarker in patients with kidney disease.

\section{Acknowledgments}

The study was supported by a grant from the Internal Grant Agency of the Czech Ministry of Health (NS/10043-4/2008). The authors are grateful to the laboratory staff Dita Hudcová, Helena Miškovská, and Jana Švarcová, MSc, for technical assistance. The authors are equally grateful to nurses from the Outpatient Department and Dialysis Centre, especially Martina Rủžičková, Bc., Hana Čejková, and Magdalena Bartková, Bc.

\section{Disclosure Statement}

No conflict of interest is declared.

References

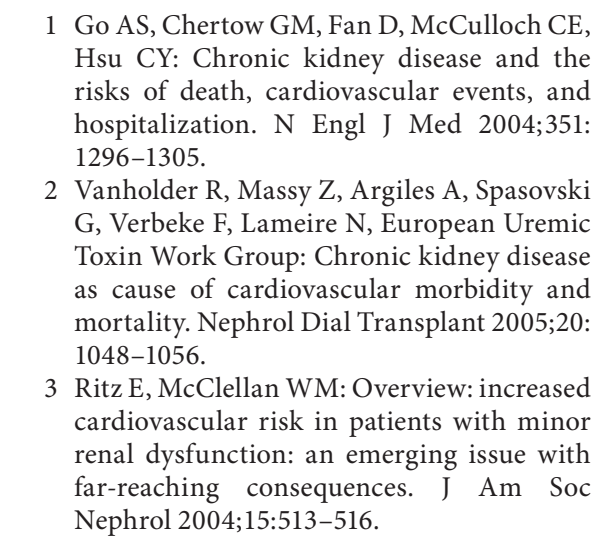

Zakiyanov/Kalousová/Kř́ha/Zima/Tesar̆ 
4 Knight EL, Rimm EB, Pai JK, Rexrode KM, Cannuscio CC, Manson JE, Stampfer MJ, Curhan GC: Kidney dysfunction, inflammation, and coronary events: a prospective study. J Am Soc Nephrol 2004;15:1897-1903.

$\checkmark 5$ Tripepi G, Mallamaci F, Zoccali C: Inflammation markers, adhesion molecules, and all-cause and cardiovascular mortality in patients with ESRD: searching for the best risk marker by multivariate modeling. J Am Soc Nephrol 2005;16:S83-S88.

6 Annuk M, Soveri I, Zilmer M, Lind L, Hulthe J, Fellström B: Endothelial function, CRP and oxidative stress in chronic kidney disease. J Nephrol 2005;18:721-726.

$\checkmark 7$ Oberg BP, McMenamin E, Lucas FL, McMonagle E, Morrow J, Ikizler TA, Himmelfarb J: Increased prevalence of oxidant stress and inflammation in patients with moderate to severe chronic kidney disease. Kidney Int 2004;65:1009-1016.

$\checkmark 8$ Yilmaz MI, Saglam M, Caglar K, Cakir E, Sonmez A, Ozgurtas T, Aydin A, Eyileten T, Ozcan O, Acikel C, Tasar M, Genctoy G, Erbil K, Vural A, Zoccali C: The determinants of endothelial dysfunction in CKD: oxidative stress and asymmetric dimethylarginine. Am J Kidney Dis 2006;47:42-50.

$\checkmark 9$ Herold K, Moser B, Chen Y, et al: Receptor for advanced glycation end products (RAGE) in a dash to the rescue: inflammatory signals gone awry in the primal response to stress. J Leukoc Biol 2007;82:204-212.

$\checkmark 10$ Basta G: Receptor for advanced glycation end products and atherosclerosis: from basic mechanisms to clinical implications. Atherosclerosis 2008;196:9-21.

- 11 Geroldi D, Falcone C, Emanuele E: Soluble receptor for advanced glycation end products: from disease marker to potential therapeutic target. Curr Med Chem 2006;13: 1971-1978.

-12 Fanconi C, Emanuele E, D’Angelo A, Buzzi MP, Belvito C, Cuccia M, Geroldi D: Plasma levels of soluble receptor for advanced glycation end products and coronary artery disease in nondiabetic men. Atheroscler Thromb Vasc Biol 2005;25:1032-1037.

-13 Koyama H, Shoji T, Yokoyama H, Motoyama K, Mori K, Fukumoto S, Emoto M, Shoji T, Tamei H, Matsuki H, Sakurai S, Yamamoto Y, Yonekura H, Watanebe T, Yamamoto H, Nishizawa Y: Plasma level of endogenous secretory RAGE is associated with components of metabolic syndrome and atherosclerosis. Arterioscler Thromb Vasc Biol 2005; 25:2587-2593.

- 14 Moroz OV, Antson AA, Dodson EJ, Burrell HJ, Grist SJ, Lloyd RM, Maitland NJ, Dodson GG, Wilson KS, Lukanidin E, Bronstein IB: The structure of S100A12 in a hexameric form and its proposed role in receptor signalling. Acta Crystallogr D Biol Crystallogr 2002;58(part 3):407-413.
5 Hofmann MA, Drury S, Fu C, Qu W, Taguchi A, Lu Y, Avila C, Kambham N, Bierhaus A, Nawroth P, Neurath MF, Slattery T, Beach D, McClary J, Nagashima M, Morser J, Stern D, Schmidt AM: RAGE mediates a novel proinflammatory axis: a central cell surface receptor for S100/calgranulin polypeptides. Cell 1999;97:889-901.

16 Yang Z, Tao T, Raftery MJ, Youssef P, Di Girolamo N, Geczy CL: Proinflammatory properties of the human $\mathrm{S} 100$ protein S100A12. J Leukoc Biol 2001;69:986-994.

17 Miranda LP, Tao T, Jones A, Chernushevich I, Standing KG, Geczy CL, Alewood PF: Total chemical synthesis and chemotactic activity of human S100A12 (EN-RAGE). FEBS Lett 2001;488:85-90.

18 Foell D, Wittkowski H, Vogl T, Roth J: S100 proteins expressed in phagocytes: a novel group of damage-associated molecular pattern molecules. J Leukoc Biol 2007;81:2837.

19 Foell D, Kucharzik T, Kraft M, Vogl T, Sorg C, Domschke W, Roth J: Neutrophil derived human S100A12 (EN-RAGE) is strongly expressed during chronic active inflammatory bowel disease. Gut 2003;52:847-853.

20 Foell D, Wittkowski H, Hammerschmidt I, Wulffraat $N$, Schmeling $H$, Frosch $M$, Horneff G, Kuis W, Sorg C, Roth J: Monitoring neutrophil activation in juvenile rheumatoid arthritis by S100A12 serum concentrations. Arthritis Rheum 2003;50:12861295.

21 Ross R: Atherosclerosis - an inflammatory disease. N Engl J Med 1999;340:115-126.

-22 Foley RN, Parfrey PS, Harnett JD, Kent GM, Martin CJ, Murray DC, Barre PE: Clinical and echocardiographic disease in patients starting end-stage renal disease therapy. Kidney Int 1995;47:186-192.

-23 Mori Y, Kosaki A, Kishimoto N, Kimura T, Iida K, Fukui M, Nakajima F, Nagahara M, Urakami M, Iwasaka T, Matsubara H: Increased plasma S100A12 (EN-RAGE) levels in hemodialysis patients with atherosclerosis. Am J Nephrol 2009;29:18-24.

-24 Uchiyama-Tanaka Y, Mori Y, Kosaki A, Kimura T, Moriishi M, Kawanishi H, Matsubara H: Plasma S100A12 concentrations in peritoneal dialysis patients and subclinical chronic inflammatory disease. Ther Apher Dial 2008;12:28-32

25 Basta G, Leonardis D, Mallamaci F, Cutrupi S, Pizzini P, Gaetano L, Tripepi R, Tripepi G, De Caterina R, Zoccali C: Circulating soluble receptor of advanced glycation end product inversely correlates with atherosclerosis in patients with chronic kidney disease. Kidney Int 2010;77:225-231.

26 Kalousová M, Hodková M, Kazderová M, Fialová J, Tesař V, Dusilová-Sulková S, Zima T: Soluble receptor for advanced glycation end products in patients with decreased renal function. Am J Kidney Dis 2006;47:406411.
27 Kalousová M, Jáschymová M, Mestek O, Hodková M, Kazderová M, Tesař V, Zima T: Receptor for advanced glycation end products - soluble form and gene polymorphisms in chronic haemodialysis patients. Nephrol Dial Transplant 2007;22:2020-2026.

28 Franke S, Müller A, Sommer M, Busch M, Kientsch-Engel R, Stein G: Serum levels of homocystein, homocystein metabolites, and of advanced glycation end products (AGEs) in patients after renal transplantation. Clin Nephrol 2003;59:88-97.

29 Nakashima A, Carrero JJ, Qureshi AR, Miyamoto T, Anderstam B, Bárány $\mathrm{P}$, Heimbürger O, Stenvinkel P, Lindholm B: Effect of circulating soluble receptor for advanced glycation end products (sRAGE) and the proinflammatory RAGE ligand (EN-RAGE, S100A12) on mortality in hemodialysis patients. Clin J Am Soc Nephrol 2010;5:22132219.

30 Basta G, Sironi AM, Lazzerini G, Tel Turco S, Buzzigolu E, Casolaro A, Natali A, Ferrannini E, Gastaldelli A: Circulating soluble receptor for advanced glycation end products is inversely associated with glycemic control and S100A12 protein. J Clin Endocrinol Metab 2006;91:4628-4636.

31 Shishibori T, Oyama Y, Matsushita O, Yamashita K, Furuichi H, Okabe A, Maeta H, Hata Y, Kobayashi R: Three distinct anti-allergic drugs, amlexanox, cromolyn and tranilast, bind to S100A12 and S100A13 of the S100 protein family. Biochem J 1999;338:

32 $\begin{aligned} & 583-589 . \\ & \text { Basta G, Sironi AM, Lazzerini G, Del Turco }\end{aligned}$ S, Buzzigoli E, Casolaro A, Natali A, Ferrannini E, Gastaldelli A: J Circulating soluble receptor for advanced glycation end products is inversely associated with glycemic control and S100A12 protein. Clin Endocrinol Metab 2006;91:4628-4634.

-33 Hasegawa T, Kosaki A, Kimura T, Matsubara H, Mori Y, Okigaki M, Masaki H, Toyoda N, Inoue-Shibata M, Kimura Y, Nishikawa M, Iwasaka T: The regulation of EN-RAGE (S100A12) gene expression in human THP-1 macrophages. Atherosclerosis 2003;171:211218.

-34 Foell D, Kane D, Bresnihan B, Vogl T, Nacken W, Sorg C, Fitzgerald O, Roth J: Expression of the pro-inflammatory protein S100A12 (EN-RAGE) in rheumatoid and psoriatic arthritis. Rheumatology 2003;42: 1383-1389.

-35 Foell D, Seeliger S, Vogl T, Koch HG, Maschek H, Harms E, Sorg C, Roth J: Expression of S100A12 (EN-RAGE) in cystic fibrosis. Thorax 2003;58:613-617.

$>36$ Foell D, Ichida F, Vogl T, Yu X, Chen R, Miyawaki T, Sorg C, Roth J: S100A12 (ENRAGE) in monitoring Kawasaki disease. Lancet 2003;361:1270-1272. 
>37 Komatsuda A, Ohtani H, Wakui H, Chyzh KA, Hatakeyama T, Iwamoto K, Maki N, Kimura T, Hitomi J, Sawada K: Increased serum levels of S100A12 in patients with MPO-ANCA-associated glomerulonephritis. Clin Nephrol 2006;66:315-321.

>38 Kosaki A, Hasegawa T, Kimura T, Iida K, Hitomi J, Matsubara H, Mori Y, Okigaki M, Toyoda N, Masaki H, Inoue-Shibata M, Nishikawa $M$, Iwasaka $T$ : Increased plasma S100A12 (EN-RAGE) levels in patients with type 2 diabetes. J Clin Endocrinol Metab 2004;89:5423-5428.

39 Verma S, Devaraj S, Jialal I: Is C-reactive protein an innocent bystander or proatherogenic culprit? C-reactive protein promotes atherothrombosis. Circulation 2006;113:21352150 .
40 Romão JE Jr, Haiashi AR, Elias RM, Luders C, Ferraboli R, Castro MC, Abensur H: Positive acute-phase inflammatory markers in different stages of chronic kidney disease. Am J Nephrol 2006;26:59-66.

41 Mahajan N, Bahl A, Dhawan V: C-reactive protein (CRP) up-regulates expression of receptor for advanced glycation end products (RAGE) and its inflammatory ligand ENRAGE in THP-1 cells: inhibitory effects of atorvastatin. Int J Cardiol 2009;142:273-278.
42 Fuellen G, Foell D, Nacken W, Sorg C, Kerkhoff C: Absence of S100A12 in mouse: implications for RAGE-S100A12 interaction. Trends Immunol 2003;24:622-624.

$\checkmark 43$ Hochepied T, Berger FG, Baumann H, Libert C: Alpha(1)-acid glycoprotein: an acute phase protein with inflammatory and immunomodulating properties. Cytokine Growth Factor Rev 2003;14:25-34.

44 Forbes JM, Thorpe SR, Thallas-Bonke V, Pete J, Thomas MC, Deemer ER, Bassal S, El-Osta A, Long DM, Panagiotopoulos S, Jerums G, Osicka TM, Cooper ME: Modulation of soluble receptor for advanced glycation end products by angiotensin-converting enzyme-1 inhibition in diabetic nephropathy. J Am Soc Nephrol 2005;16:2363-2372. 